\title{
The Validity of the Action Taken With Respect to Greenland in 1941
}

\section{Edmund H. Kellogg*}

$T_{\text {States Government and by M. Me Kaufmann, the Danish Minister }}^{\text {He }}$ to the United States, on April 9, 1941. ${ }^{1}$ Under this agreement, the United States Government obtained defensive bases in Greenland and undertook to assist that island in the maintenance of its existing status until-such time as the dangers to the Amerrican Continent arising from Hitler's war of conquest shall have passed.

The validity of this agreement, together with the action taken thereunder by the United States Government, is open to some question, particularly at first glance. First, the Danish Government never vested any authority in $M$. de Kauffmann to cede any of the national territory. Secondly, the agreement was not at any time ratified by the competent Danish authorities. These points, and others of less importance, have been raised in an mteresting article by a learned authority on international law. ${ }^{2}$

It is conceded that there is not, under normal circumstances, any authority in ambassadors or ministers to cede national territory. It is also conceded that such an agreement would normally require the ratification of the home government, even if the authority to sign such an agreement had been granted. However, it is believed that once the agreement an daction are viewed, not as isolated transactions, but as part of a series of related events, their validity will become apparent.

Henrik de Kauffmann was recognized by the United States Government as the accredited representative of Denmark on Augnst 26, 1939. On April 9, 1940, the territory of Denmark was invaded by Germany without warning and in flagrant disregard of international law. ${ }^{3}$ The invasion of Denmark by Germany was merely one of a series of acts by that state which destroyed or threatened to destroy every vestige of international law on the Continent of

*Member of the New York Bar.

\footnotetext{
14 State Departarent Bulletin (1941) at 443, 445.

2 See Briggs, Comment (1941) 35 AM. J. INT. Law 506.

3 As to the German Government's excuse that this was in self-defense, sce infra
} p. 155 . 
Europe. On the day after the invasion, M. de Kauffmann issued a public declaration denouncing the invasion and announcing that he would remain independent of any German pressure. ${ }^{4}$ In spite of the publicity given to this declaration the authorities in Copenhagen made no move to recall him for a year. On May 3, 1940, the Greenland Councils, meeting in Gadhavn, adopted a resolution in the name o fthe people of Greenland which, in effect, invited the United States Government to assist them in the defense of their existing status in view of "the exposed position of the Danish flag in Greenland" in the face of the German threat. ${ }^{5}$ At Habana, in August 1940 the foreign ministers of all the American Republics declared that there was a grave danger of "attempts at conquest" arising out of the European war and, further, that there was a danger that European territorial possessions in America might be converted into "strategic centers of aggression" against the American Continent. Accordingly, emergency machinery was provided on the basis of which any of the American Republics, individually or jointly, would take the action required under the circumstances. ${ }^{6}$ In March, 1941, unmistakable evidence became apparent of the intention of the Germans to establish themselves in Greenland for the purpose, not only of attacking the Atlantic sea routes, but also of attacking this hemisphere itself. ${ }^{7}$

It was in the light of these facts that the Government of the United States, not only in pursuance of its policy of aid to those democracies who are fighting for the very existence of international law, but also to protect itself and its neighbors from an immediate and threatening danger, took the only steps possible: (1) it negotiated with the sole available representative of the Danish King and Government who had been duly appointed by that Government and who could negotiate and act without duress; (2) it took coguizance of the invitation contained in the resolution of the Greenland Councils; (3) it notified the other American Republics; and (4) it sent armed forces to Greenland to occupy those parts of the island which were threatened by Germany and to establish bases for the protection of Atlantic shipping.

After the announcement of the agreement, the authorities in Copenhagen repudiated it and recalled M. de Kauffmann. However,

1 New York Times, April 10, 1940, at 12.

54 State Departanent Bulleten, supra note 1, at 444.

${ }^{6} 3$ ibid. (1940) 138.

7 Supra note 5. 
it should be noted that they did not request the recall of the United -States Legation in Copenhagen and that no substitute minister was sent to this country. In this way the authorities indicated in the clearest manner available to them that the agreement had their tacit approval and that they wished to maintain contact with the United States Government and even with $M$. de Kauffmann himself. ${ }^{8}$

On the basis of the essential facts just outlined, it is believed that the agreement is valid and binding under principles of justice and common sense recognized in both international and nuunicipal law.

There is a doctrine recognized by nearly all systems of municipal law which precisely covers the facts of this case. This doctrine provides that if an emergency occurs which renders a person unable to act for himself or to authorize and agent to act for him, and if his property or business is left unprotected as a result of this situation, then an existing agent who has not been given the necessary authority in the past, or even a mere volunteer, will be deemed to become vested with sufficient authority to act for the protection of the interests of the incapacitated principal.

This doctrine is recognized in the common law as is pointed out in the Restatement of Agency. ${ }^{\circ}$

"Unless otherwise agreed, if after the authorization (of an agent) is given, an unforeseen situation arises for which the terms of the authorization make no provision and it is impracticable for the agent to communicate with the principal, he is authorized to do what he reasonably believes to be necessary in order to prevent substantial loss to the principal witl respect to the interests committed to his charge."

The same principle is recognized in the applicable cases both in England and in the United States. ${ }^{10}$

8 The increasing rioting among the Danish population which has reached a climax this year, together with the confinement of the King and his ministers during the summer of 1943, offer further proof-if any is needed-of the attitude of the competent Danish authorities in this matter.

9 Restatenent of the Law of Agency (Am. L. Inst., 1933) §47.

10 Langan v. Great Western R. R. Co. (1873) L. R. 2 Exch. 228 (L.T.), 30 L.T.N.S. 173; Sherman's Estate (1888) $6 \mathrm{~Pa}$. Co. 225 (Contract retaining consultant physician when principal rendered incoherent by brain disorder upheld); Sheehan v. Elhott Manufacturing Co. (1929) 83 N.H. 642, 145 Atl. 139; de Pasquale v. Societa et al (1934) 54 R.I. 399, 173 Atl. 623; STORY, AGENCY (Green, 8th ed. 1874) \$141, giving excellent collection of English and early United States cases; 2 C. J. S. 1015, at 1062, the text reads, "Agency may be implied by law, and may be implied where the acts of a self- 
This doctrine is also fully accepted in Danish law, ${ }^{11}$ in terms of which the authority of $M$. de Kauffmann must be interpreted. The Danish rule is derived from the doctrine of Roman Law known as "Negotiorum Gestio,"12 and is, accordingly, in agreement with the other systems of municipal law on the European Continent, derived from Roman Law.

As will be more fully appointed out below (page 000) in connection with the doctrine of self-defense, principles of municipal law under which, in emergency situations, special and unusual rights and duties may arise, are far more applicable to international situations than to intra-national situations which are, under normal circumstances, governed by a competent police and judiciary. It is obvious that emergencies, often arising from the illegal act of some lawless state, are more apt to occur in the international sphere than the municipal sphere.

In fact, international law does accept and apply this principle. Under established practice during the nineteenth century and particularly since the signing of the Pact of Paris, the Government of the United States is, of course, within its rights under international law in not recognizing the illegal invasion of Denmark and in continuing to recognize the representative of the Danish Government appointed at a time when that Government could act freely and without duress. ${ }^{13}$ This right is based, not only upon the right of any sovereign government to recognize or not to recognize as it may see fit, and not only upon the agreement of civilized states inherent in the Pact of Paris, ${ }^{14}$ but upon the fundamental principle that a nation should not be deprived of its voice and its right to act for itself, and that its interests

constituted agent are, by reason of ... the Act of God, necessary for the self-preservation of the principal or the well-being of society, as where the principal is so incapacitated by injuries that he is unable to act for himself."

11 See Lassen, Laerebog I Obligationsrettens, Specietue Ded (Ussing, 1924) $462-472$.

12 The doctrine of Negotiorum Gestio is substantially the same as its modern Danish equivalent. See Hunter, Ronean Law (4th ed. 1903) 661 et seq; Shrerscan, EprTome OF ROASAN LAW (1937) 181.

${ }^{13}$ See Stowell, Comment (1940) 34 Axr. J. INT. LAw 310, 311-312.

14 Wright, The Meaning of the Pact of Paris (1933) 27 AMr. J. Int. Law 39, 49-50. See also international resolutions and treaties embodying the doctrine of "Non-Recognition," collected in this Journal (1939) Supp. Vol. 33, pp. 889-895. Resolution No. XXVI of the Eighth International Conference of American States (Lima, Dec. 1938) declares, "the pledge of non-recogmition of situations arising from the foregoing conditions [by aggression] is an obligation which cannot be avoided either unilaterally or col-: lectively." 
should not be left unprotected, as the result of an illegal act committed against it.

It has been the unquestioned practice of the United States Government to recognize the authority of representatives of states whose governments have been subjected to similar emergencies. Such authority has been recognized although the government which had appointed these representatives no longer governed the national territory. ${ }^{15}$ Thus, Señor Romero, the Minister of the Juarez Government of Mexico, was recognized by the United States Government throughout the time of the French occupation of that cormtry during the $1860^{\prime} \mathrm{s} .{ }^{16}$. M. Bakhmetieff continued to be recognized as the Ambassador of Russia long after the Kerensky Government had been overthrown. ${ }^{17}$ And the Belgian Minister was recognized throughout the First World War in spite of the fact that his country was almost entirely overrun and in spite of the fact that his government was in exile. $^{18}$

A close analogy to the case of M. de Kauffmaim is the case of M. Bakhmetieff whose position was reviewed by the United States courts on several occasions in the Lehigh Valley Cases. ${ }^{10}$ In the Lehigh Valley Cases the Federal courts upheld the right of M. Bakhmetieff, as the recognized representative of the State of Russia, to take important action with respect to the property of that State. ${ }^{20}$ The District Court of New York pointed out the importance of the recognition of some representative who would be in a position fairly to maintain the rights of his state, which had been incapacitated by an emergency from acting for itself in a normal manner. ${ }^{21}$

15 Under international practice, the agent of a government may be recognized and may negotiate agreements vitally affecting his government and its property, although that government does not, at the time, occupy any of the national territory to which it may lay claim. Thus, toward the end of the First World War, the United States Government, together with the governments of France and Great Britain, recognized the "national committees" of the Poles and Czechs and even recognized as vahd the financial obligations which were then floated by their representatives although at the time the national territory of these states was wholly outside the control of these "committees." See 1 Hack Worth, Digest of International LAW (1940) 203-208, 214-217.

161 MOORE, Digest OF INTERNationat LAW (1906) 184.

1728 AMr. J. INT. Law (1934 Supp.) 15, 16.

18 See Diplonatic Lists of the U. S. Dept. of State 1914-1918, also The Journat OF BRAND WHTLLOCK (1936) 379.

19 (D. N.Y. 1919) 293 Fed. 133; (D.N.Y.1923) 293 Fed. 135; (C.C.A. 2d 1927) 21 F. (2d) 396, cert. den., (1927) 275 U.S. 571.

20 The right of M. Bakhnetieff to bring suit on claims in favor of the Russian state and to enploy counsel for this purpose was upheld.

21 (D. N.Y. 1923) 293 Fed. 135, at 138. 
But the authority of $M$. de Kauffmann rests on stronger foundations than that of $M$. Bakhmetieff. M. Bakhmetieff's government had been overthrown by revolution, which is, of course, not of itself illegal in the eyes of international law. Moreover, the authority and physical power of M. Bakhmetieff existed only within the United States and only to the extent which the United States Government might see fit to permit as a matter of policy. On the other hand, M. de Kauffmann lost contact with his government only as a result of the imternationally unlawful act of another state, which had also infringed the rights of the United States and of every other neutral power. In addition to this, the actual population of Greenland, the territory affected by the agreement, recognized M. de Kauffmann's authority to act and agreed with what he did. Thus, in making the agreement, $M$. de Kauffmann acted on behalf of a population who recognized his authority to do so, and who actually had the physical power to put it into effect.

On the basis of the above principles, it is submitted that the agreement is entirely valid and would be recogmized as such before any unbiased international tribunal.

In order, however, to get a complete understanding of this question, it is believed that, even if there had been no agreement whatsoever, still the action of the United States Government in Greenland would have been wholly legal and justified, under the circumstances.

At the time that the bases were established, the Danish Government in Copenhagen was subject to the illegal but complete control of the German Government. It could not act to govern Greenland. ${ }^{22}$ At the same time, the Germans by their occupation of Denmark derived no right whatsoever to govern Greenland. By the terms of the Hague Conventions of 1899 and 1907, territory is considered "occupied" only when it is "actually placed under the authority of the hostile army."23 "Occupation then is a question of fact and follows the army."24 Thus, even if the German Government obtained the right of a belligerent occupant to govern the territory under occupation, this extended only to Denmark proper and the Germans obtained no rights whatsoever to govern Greenland by so doing.

22 HYDE, INTERNATTONAL LAW (1922) 362-363, showing that an army of occmpation deprives the de jure sovereign of the power to govern.

23 Article 42 of the Laws and Customs of War on Land, The Hague Conventrons and Declarations of 1899 and 1907 (Carnegie Endowment Ed. 1915) 122.

24 Woolsey, Comment (1938) 32 AMr. J. INT. LAw 314, at 318. See also 2 HYDE, op. cit. supra note 22, at 362; 2 OpPENHEns, INTERNATTONAL LAW (Lauterpacht 6 th ed. 1940) at 341 et seq. 
Thus, in such a situation, the only government which had the right to speak for Greenland (other than M. de Kauffmann) with any color of authority whatsoever was the local government represented by the Greenland Councils, and that government invited the action taken by the United States Government.

But even should it be held that the Councils had no authority to act under the circumstances, it must then be admitted that there was no authority anywhere (again except for M. de Kauffmann). Sovereignty was accordingly temporarily suspended so far as Greenland was concerned. But in such a case the United States Government had a right to intervene in accordance with the rule of international law under which one state may intervene in the territory of another state when, at the time, there is no governmental authority whatsoever in the territory concerned. ${ }^{25}$ Thus, the United States forces, under similar circumstances, intervened to preserve order at Matamoros, Mexico, in 1876, at a time when revolutionary forces had abandoned the town and government forces had not yet entered it. ${ }^{26}$ Similarly, the United States forces took action at San Domingo in $1904 .^{27}$

Finally, there is another ground on which the action of the United States is fully justified on the facts of this case. That is the principle of self-defense, and the Monroe Doctrime which is an outgrowth of it.

The doctrine of self-defense is well defined by Hyde: ${ }^{28}$

"An act of self-defense is that form of self-protection which is directed against an aggressor or contemplated aggressor. No act can be so described which is not occasioned by attack or fear of attack. When acts of self-preservation on the part of a State are strictly acts of self-defense, they are permitted by the law of nations, and are justified on principle, even though they may conflict with the normal rights of other States."

The doctrine is the same as that recognized at the common law as well as in all other systems of municipal law. Not only may a man use force in self-defense directly against an attacker, ${ }^{29}$ but he may trespass upon the property of a third party if this be necessary for his protection. Thus in the earliest times it was held in Mouse's Case

25 Baty, Abuse of Terms: Recognition; War (1936) 30 Axc. J. INT. LAw 377, at 385.

28 Clark, Right to Protect Citizens in Foreign Countries (Mesrorandusc or SoITCTTOR OF THE U.S. DEPT. OF STATE, 1934) 67.

27 Baty, supra note 25 , at 385 .

281 HYDE, op. cit. supra note $22,106$.

29 Beard v. United States (1895) 158 U.S. 550.

30 (1609) 12 Coke 63. 
that one passenger on a boat was not liable for throwing overboard the property of another passenger during a storm when, had this not been done, all the passengers would have been drowned. The same doctrine was restated even more strongly in the case of Ploof $v$. Putnam. ${ }^{31}$

If this doctrine is recognized in the field of municipal law where there is nearly always a strong police force available to maintain order and where emergencies are comparatively rare, the doctrine is far more applicable in the field of international law where there has so far been established no comparable police force. This analogy las been recognized by many authorities on international law. ${ }^{32}$ Thus Wright, in his article, "The Outlawry of War"33 states:

"Systems of private law always recognize the right of an individual to commit acts otherwise illegal, if necessary for his own preservation from attack or for the prevention of impending illegal acts. It is true, they require that a recognized procedure be followed if possible but occasions may arise in the best governed state when self-help is the only resort. Such occasions arise more frequently in the society of nations because of the lack of international police. International law clearly recognizes that in such circumstances, acts having the character of acts of war are justified, if necessary for defense of territory or citizens against an 'instant and overwhelming' danger."

The right of a state, in self-defense, to anticipate a threatening serious injury and, if need be, to enter by force upon the territory of another state to prevent that injury, is recognized by every authority on international law. ${ }^{34}$ This doctrine is based, in part, upon the

31 (1908) 81 Vt. 471, 71 Atl. 188. In that case the owner of a boat attempted to tie up at a wharf during a storm and was cast-off by the owner of the wharf. The ship owner sued the wharf owner for the damages caused by the resulting wreck, and recovered in full.

32 Hatx, INTERNattonat LAw (8th ed. 1924) 65; Stowetx, INTERVEation IN INTERNATTONAL LAW (1921) 405; WESTLAKE, INTERNATIONAL LAW (1910) 312.

33 (1925) 19 Axr. J. INT. LAw 76, at 90.

34 BLUNTSCHLT, INTERNATIONAL LAF (Lardy, French translation, 1870) \$\$479, 782; BRIERLX, ThE LAF of NATIONS (2d ed. 1936) 253; Clark, op. cit. supro note 26, at

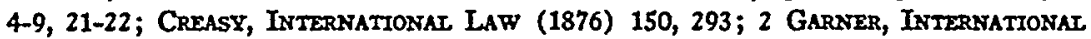
LAW AND THE WORLD AT WAR (1920) 193; HALI, op. cit. supre note 32, at 54, 322; 1 Hatteck, Internationas LaW (4th ed. 1908) 102, 104-105; Hershey, The Essentials of Internationar Publtc Law (rev. ed. 1927) 232, 238; Lawrence, The Princaples of INTERNATIONAL LAw (7th ed. 1923) 125; 8 MOORE, op. cit. supra note 16, at 2; 1 Oppeniens, International Law (Lauterpacht 5th ed. 1937) 243 et seq.; 1 Peilli-

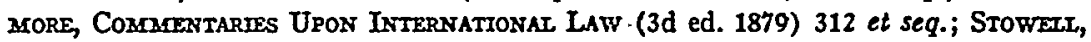
op. cit. supra note 32, at 373 et seq.; 3 VATIRI, ThE LAW of Natrons (Camegie Inst. 
obvious uselessness of invoking, in this type situation, the "remote and powerless legitimate sovereign or his representatives on the spot." 35

Of course, the most important consideration in connection with the doctrine of self-defense is the facts of the case. It is essential that there be an actual and imminent threat which can not be forestalled by any other means than swift action on the part of the threatened state. That such a situation existed in this case seemed clear enough at the time. However, subsequent events have more than proved how reasonable were the suspicions of the United States Government. Only a little over two months after the action was taken with respect to Greenland, Germany attacked Russia, with whom she had a non-aggression pact, without any warning. Seven months afterwards, Germany's ally, Japan, with German connivance, attacked Pearl Harbor, whereupon Germany instantly declared war on the United States. Clearer proof could scarcely be given of the aggressive intentions of the German Government. Moreover, on frequent occasions since the date of the Agreement, there have been well substantiated press reports of the use by the Germans of the territory of Greenland in furtherance of these aggressions. ${ }^{36}$

It nust, of course, be reinembered that the doctrine of self-defense

Ed., 1916) 8, 14, 130, 243; WESTLAKE, op. cit. supra note 32, part 1 at 309 et seq.; Wreaton, ELEMENis of INTERNationat Law (Carnegie Inst. Ed., 1916) 75; Kulsrud, The Seizure of the Danish Fleet 1807 (1938) 32 Axr. J. INr. LAw 280, at 310-311; Stimson, The Pact of Paris; Three Years of Development, 11 Foreign Affairs, Special Supplement No. 1, at 5; Fenwick, Comment (1940) 34 AMr. J. INr. Law 697, at 698; Finch, Comment (1917) 11 AM. J. InT. LAw 399, at 406.

35 Baty, supra note 25 , at 391 ; it should be pointed out in this connection that a small neutral state whose territory may be involved in a situation of this nature is under a duty to resist as did Belgium in 1914. GARNER, op. cit. supra note 34, at 225; STowrtr, op. cit. supra note 32, at 373 . OpPENEERM, op. cit. supra note 24 , at $517,537,559$, also points this out, stating at page 559: "the neutral unust even use force to prevent belligerents from occupying any part of his neutral territory." Moreover, the fact that the neutral state is powerless to resist makes no difference to the rigbt of the threatened state or states to act. PHIIIIMORE, op. cit. supra note 34, at 317, states that the failure of the neutral state to suppress marauders is a "practical acknowledgment" of its inability to suppress them and thus justifies the intervention by other states. WESTLAKE, op. cit. supra note 32, at 302-303, says: "The principle that the legal rights of a state are not to be violated without its own fault is not really infringed [by such an intervention], for when a state is unable of itself to prevent a hostile use being made of its territory or its resources, it ought to allow proper measures of self-protection to be taken by the state against which the hostile use is impending, or else must be deemed to intend that use as the necessary consequence of refusing the permission."

${ }^{36}$ E.g., newspaper account of the raid by United States forces on a German weather station in eastern Greenland, October, 1943 . 
is often invoked by malefactor states as an excuse for aggression, contrary to the entire theory of the doctrine. Thus Germany invoked the doctrine as an excuse for its wholly illegal invasion of Belgium in 1914 , in a case where there was no threat of harn to Germany froin Belgium itself, nor was there a shread of evidence that any other nation planned to attack Germany through Belgium. ${ }^{37}$ Germany has in fact invoked the same doctrine as an excuse for her present invasion of Denmark. ${ }^{38}$ The circumstances of that invasion, like those of the Belgian case in 1914 (and in 1940), serve as an excellent illustration of the situation in which the doctrine does not apply. There was no evidence that Denmark would or could attack Germany, or that any of her territory or property would be used by Germany's enemies as a means of attack on Germany. Moreover, the previous conduct of Germany's enemies had given no indication of any ruthless disregard of law which might indicate that they would not hesitate to use Danish territory as a base for operations against Germany. Finally the offensive rather than the defensive use made of Danish and Belgian territory by Germany indicates clearly that the motives for invasion were not defensive.

There are many well recognized examples of genuine defensive action similar to that which the United States Governinent has taken in the case of Greenland. ${ }^{39}$ Moreover, the best known cases where this type of intervention has occurred-cases which are regularly cited in the texts as typical examples of justifiable self-defensebear a striking similarity to the present case and offer an equally striking contrast to the various aggressions of the Germans undertaken under the excuse of self-defense. Among these are: the intervention of General Jackson in Florida in 1814 and $1817^{40}$ against the English and pirates, who had established themselves there as the result of the powerlessness of the Spanish authorities to remove

372 GARNER, op. cit. supra note 34, at 191.

$38 \mathrm{New}$ York Times, April 10, 1940, at 10. The German memorandum to Denmark even claimed: "German military operations are aimed at the exclusive goal of safeguarding the Danes against the intended occupation of Danish strategic points by English and French forces."

39 Among the lesser known examples are: the action taken by the United States in the suppression of the Cuba pirates in 1823 (see meinoradum of Clark, op. cit. supra note 26, at 53) ; and the British action in connection with the mobilization of the Spanish fleet at Ferrol in 1804 [LawREnce, Internationax LAw (3d ed. 1900) 121].

401 HrDE, op. cit. supra note 22, at 109; 2 MOORE, op. cit. supra note 16, at 402 et seq.; 1 ORPENHENA, op. cit. supra note 34, at 246; 1 WHARTON, INTERNATIONAI LAW (2d ed. 1887) \$\$50a, 50b. 
them; the Caroline incident in 1837 when the Canadian authorities took action on United States territory to suppress rebels who were being harbored by the local authorities; ${ }^{41}$ the intervention by United States forces in Mexico in pursuit of lawless bandits on various occasions during the Nineteenth and early Twentieth Centuries; ${ }^{42}$ and finally the seizure by the British of the Danish fleet at Copenhagen in $1607 .^{43}$

The Danish fleet incident has recently been well covered by a leading article in the American Journal of International Law. ${ }^{44}$ The article gives a complete factual background which shows how similar the facts of that case were to those here. The author, after examining in detail into the Danish archives of the period, shows how inmediate was the danger which threatened the British and shows how clear was their justification, under the doctrines of international law, in taking action. In both cases, the small and weak neutral nation of Denmark was being subjected to great pressure by an aggressive dictator who had flagrantly disregarded all the rules of international law, who had overrun the Continent of Europe, and who was engaged in a death struggle with England. In both cases it was clear that this dictator had the immediate intention of seizing an extremely strategic part of Danish property with which he could attack the sea routes vital to England's survival. In both cases preventive action was taken only when it was apparent that Denmark could do nothing and no other means were available to prevent the threatened danger. The only differences between the two situations tend toward making the case for the Greenland intervention stronger than was the case for intervention in 1807.

\footnotetext{
41 See authorities listed in the preceding note (40) and, in addition, BRIERLY, op. cit. supra note 34, at 253; Jennings, The Caroline and McLeod Cases (1938) 32 Axr. J. INT. LAw, at 82. The latter authority gives a full account of the incident and points out that it is of particular significance since, in that case, the state upon whose territory the intervention took place was powerful and, accordingly, the definition of the right to intervene in self-defense which grew out of that incident reflects a genuinely bilateral controversy. Ibid. at 92.

422 MOORE, op. cit. supra note 16, at 418 et seq., pointing that that it was admitted by the Secretary of State of the Uurited States (p. 421) that intervention in pursuit of bandits was permissible in both directions; WESTLAEE, op. cit. supra note 32, at 302, note 2; Finch, Counment, op. cit. supra note 34, at 406 .

13 Although this incident may have been criticized as unjustifiable by various Continental writers during the Nineteenth Century, it appears to be now generally accepted by the more modern authorities, e.g., Haxr, op. cit. supra note 32, at 326; HERSHEx, op. cit. supro note 34, at 232, 238; STOWEL, op. cit. supra note 32, at 413; WESTLAXE, op. cil. supra note 32 , at 302 .

14 Kulsrud, supra note 34 , at 280.
} 
The first difference is the fact that, in 1807 , Napoleon had only indicated by a secret provision of the Treaty of Tilsit that he was willing to violate the neutrality of Denmark in order to obtain his ends. Thus there was some ground for the belief of writers attacking the action of the British that he might not have put this intention into effect. On the other hand, in the present case, the Germans had actually invaded Denmark without color of right, they had used and were using Danish territory as a basis for further aggressions, and they had already sent their forces into the Greenland area at the time that the United States action was taken.

The second difference arises from the fact that, in 1807, action was taken by a state which was actually at war with the Continental aggressor, whereas, in the present case, war had not been actually declared between the United States and Germany at the time of the intervention in Greenland. This aspect of the situation, of course, makes no difference in the application of the doctrine of selfdefense, ${ }^{46}$ but it raises for consideration another doctrine of international law, related to the doctrine of self-defense, to the effect that any neutral nation may intervene for the vindication of international law when the fundamental basis of that is menaced.

Vattel states: ${ }^{46}$

"If, then, there should be found a restless and unprincipled Nation, ever ready to do harm to others, to thwart their purposes, and to stir up civil strife among their citizens, there is no doubt that all the others would have the right to unite together to subdue such a Nation, to discipline it, and even to disable it from doing further harm."

The principle thus laid down by Vattel has been generally accepted by the authorities since his time, who have agreed that neutral nations have the right, and at times the duty, to intervene to protect the principles of international law and order. ${ }^{47}$

One aspect of this rule has been the recognized right of a state to intervene in the affairs of a small state to expel or to limit an

15 Hyde, Comment (1941) 35 Axr. J. Int. LAw 117, at 118.

103 VATTEI, op. cit. supra note 34, at 130.

47 Fenwick, Comment, op. cit. supra note 34, at 698; 1 Oppenerets, op. cit. supra note 34, at 252; WESTIAKE, op. cit. suppra note 32, at 304; Wright, op. cil. supra note 33; at 92 ; StowerI, op. cit. sufpra note 32, at 406 , points out that a neutral has a duty to protect his territory from hostile action by belligerents but that, under the usual circumstances, the neutral will be too weak effectively to perform its duty. Accordingly, the necessity is pointed out that powerful nations will, in such cases, intervene to protect weal neutrals as has been done in this case. 
illegal intervention in the small state by a third state. ${ }^{48}$

Thus, the intervention by England in the affairs of Portugal in 1826 in order to suppress the attempt of Spain to depose the reigning sovereign of Portugal have been generally accepted as legal. ${ }^{40}$ Similarly, the mtervention of the United States in Mexico in 1865 and 1866, which was instrumental in thwarting the French intervention in that country, was of unquestioned legality. ${ }^{50}$

These principles of law have been corroborated and implemented by recent inultilateral agreements. Thus, Articles 10, 11, 16, and 17 of the League Covenant recognize the duty of neutrals to act under such circumstances. ${ }^{51}$ Furthermore, under the Pact of Paris the rights of the United States and all the other signatories have been infringed by the acts of Germany. ${ }^{52}$ Accordingly, there can .be no basis for a claim that the United States had any less right to intervene in Greenland merely because it did not happen to be at war with Germany at the time. Its security and rights as a neutral were so gravely threatened and infringed that it had ample justification to take the requisite steps for the protection of itself and of the other law-abiding nations of the Western Hemisphere.

Before concluding consideration of the doctrine of self-defense, some mention should be made of the Monroe Doctrine. That Doctrine had its origin in the right of self-defense, as President Monroe's declaration plainly stated.

"We owe it, therefore, to candor and to the amicable relations existing between the United States and those powers [in Europe] to declare that we should consider any attempt on their part to extend their system to any portion of this hemisphere as dangerous to our peace and safety,"153

As a declaration based upon the right of self-defense, the Doctrine is

18 Buontsciri, op. cit. supra note 34, 8479 ; Creasy, op. cit. supra note 34 , at 295 ; HERSHEY, op. cit. supra note 34, at $238 ; 1 \mathrm{HYDE}$, op. cit. supra note 22, at 119; LAWRENCE, op. cit. supra note 34 , at 124.

49 E.g., CreasY, op. cit. supra note 34, at 295; 1 HYDE, op. cit. supra note 22, at 120 (note 1) ; PHIIITMORE, op. cit. supra note 34, at 315 .

50 E.g., BLUNischil, op. cit. supra note 34,$8479 ; 1 \mathrm{HYDE}$, op. cit. supra note 22, at 120 (note 1); LAWRENCE, op. cit. supra note 34, at 124.

51 Essential Facts About the League of Nations (League of Nations, Secretariat, Information Section, 1938) 16, 17, $20-23$.

62 Jackson, Address at Inter-American Bar Association Meting in Havana (1941) 35 Ax. J. INT. LAw 348, at 353-354; Wright, op. cit. supra note 14, at 59.

53 Address of President Monroe, December 2, 1823, see Clark, The Monroe Doctrine (Memoranduar of State Department of U.S. Goyernanent, 1930). 
sound under international law. ${ }^{54}$ Thus, the action taken in Greenland is justified on the same legal grounds as those on which the Monroe Doctrine itself is founded.

However, even if this were not the case, the Monroe Doctrine has received the recognition of the great powers. ${ }^{55}$ Moreover, events since the first World War have given to the Monroe Doctrine such a status that it may well have become sufficient in and of itself to constitute a legal basis for the Greenland action. The inclusion of this Doctrine in Article 21 of the League Covenant, ${ }^{56}$ together with the various agreements of consultation which have been made with the other American Republics have, in the opinion of distinguished non-United States authorities, made the Doctrine an integral part of international law. ${ }^{57}$

How, then, does the Monroe Doctrine bear upon the circumstances of this case? First of all, under it, no transfer to a nonAmerican government of territory within the American hemisphere, which includes Greenland, ${ }^{58}$ is permissible. Under it, also, the United States Government is committed to take the necessary measures to prevent a threat to the American hemisphere, particularly when that threat is accompanied by the threat of a non-American power to seize American territory. It might also be noted, in passing, that the Monroe Doctrine offers a significant contrast to the German "New Order" or the Japanese "Co-Prosperity Sphere." Whereas the latter are mere cloaks for aggression against neighboring countries of the most selfish and irresponsible nature, under the Monroe Doctrine, the United States assumes responsibility for the maintenance of the liberty and rights of its neighbors, among which is Greenland.

Thus, even if all the other grounds which have been set forth for the validity of the Greenland agreement and action were invalid, the Monroe Doctrine alone offers an ample foundation for them.

In conclusion, it is submitted that if such an agreement as the one

54 1 HYDE, op. cit. supra note 22, at 142 ; and see authorities collected in Clark, opcil. supra note 53.

55 Thus, the Doctrine was accepted by England at the time of the Venezuela crisis in 1895. See 1 Hyde, op. cit. supra note 22 , at 147 .

56 Essential Facts About the League of Nations, op. cit. supra note 51, at 24.

57 Luis ANderson (of Costa Rica) Proceedings of Asmerican Soctety of INTerNational LaW (1912) 72, at 81; 1 Fauchille, Droit Internationaz Public (8th ed. 1923) Part 1 at 545; 1 WheATON, INTERNATIONaI LAW (Keith, 6th English ed. 1929) 147.

68 Martin, The Geography of the Monroe Doctrine (1940) 30 GEoG. REv. 525, at 527; Boggs (Geographer of the U.S. Dept. of State) letter to Congresswoman Rogers (1940) 86 Cong. Rec., part 16, p. 3683. 
under present consideration were to be held invalid, then a wrongdoer would be legally permitted to benefit by his own wrongdoing. Germany, by the clearly illegal seizure of Denmark, could then legally force that country to cede Greenland to it contrary to the wishes of its entire population. At the same time it could make it legally impossible for neutral powers, or for such agents of Denmark as remain free, not only to protect other states from the obvious danger of German aggression, but also to protect the interests of Denmark herself. Such a doctrine is obviously repugnant to any system of law whatever, whether mumcipal or international. As Oppenheim says, "An unlawful act cannot normally produce results beneficial to the lawbreaker." 